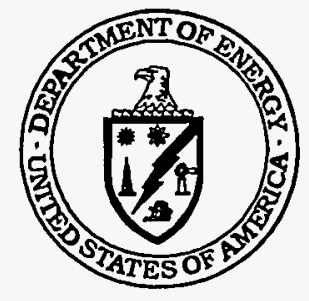

\title{
Ignitable, Corrosive, Reactive, and Incompatible Wastes Information Brief
}

BACKGAOUND: Under RCRA Subtitle c, a solid waste can be deemed hazardous if, among other things, it exhibits
one or more of the hazardous characteristics identified in 40 CFR 261 , Subpart C. These
characteristics are ignitability, corrosivity, reactivity or toxicity. This information brief discusses
Issues related to the management of wastes exhlbiting one or more of the three physical waste
characteristics ignitability, corrosivity, and reactivity. Generators of ignitable, corrosive and
reactive wastes must take special precautions to ensure the safe handling of these wastes and to
prevent any contact with other incompatible wastes or materials that could result in potentially
dangerous situations. Regulatory definitions, an overview, of the applicable compliance
requirements, and special considerations for the safe handing of these characteristic hazardous
or incompatible wastes are provided herein.

STATUTES: Resource Conservation and Recovery Act (RCRA)

Hazardous Materials Transportation Act (HMTA),

Hazardous Materials Transportation Uniform Safety Act (HMTUSA)

Occupational Safety and Health Act (OSHA)

ORDERS: Department of Energy Order 5480.3 "Safety Requirements for the Packaging and Transportation of Hazardous Materials, Hazardous Substances, and Hazardous Wastes," (DOE 1985)

Department of Energy Order 5400.1 "General Environmental Protection Program," (DOE 1994)

REGULATIONS: 40 CFR 261 Identification and Listing of Hazardous Waste

40 CFR 262 Standards Applicable to Generators of Hazardous Waste

40 CFR 264 Standards for Owners and Operators of Hazardous Waste Treatment, Storage, and Disposal Facilities

40 CFR 265 Interim Status Standards for Owners and Operators of Hazardous Waste Treatment, Storage, and Disposal Facilities

40 CFR 268 Land Disposal Restrictions

49 CFR 171 to 177 - Department of Transportation Hazardous Materials, Substances and Waste Regulations

REFERENCES: 1. American Society for Testing and Materials, ASTM Standard Test Methods for Flash Point of Liquids by Setaflash Closed Cup Tester, ASTM Standard D-3278-78, Philadelphia, PA.

2. American Society for Testing and Materials, ASTM Standard Test Methods for Flash Point by Pensky-Martens Closed Tester, ASTM Standard D-93-79 or D-93-80, Philadelphia, PA.

3. Department of Energy Information Brief "Pretransport Requirements for Waste Generators," EH-231-037/0394, March, 1994.

4. Environmental Protection Agency, Test Methods for Evaluating Solid Waste, Physical/Chemical Methods, EPA Publication SW-846, Third Edition (November 1986), Revision I (December 1987), Washington, DC.

5. National Assoclation of Corrosion Engineers, NACE Standard TM-01-69, Test Method Laboratory Corrosion Testing of Metals for the Process Industries, Houston, TX, 1969.

6. National Fire Protection Association, NFPA 101-1970, Life Safety Code, Boston, MA.

7. National Fire Protection Association, Flammable and Combustible Liquids Code, Boston, MA, 1981.

\section{What are ignitable wastes?}

Ignitable wastes are solid wastes (definition of "solid waste" is found at 40 CFR 261.2) that exhibit any of the following properties as defined at 40 CFR 261.21(a):

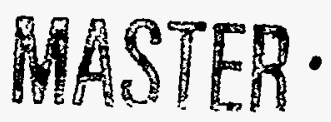

- "it is a liquid, other than an aqueous solution containing less than 24 percent alcohol by volume and has a flash point less than $60^{\circ} \mathrm{C}\left(140^{\circ} \mathrm{F}\right)$." Flash point determinations can be made by using several approved testers and test methods including the Penskv-Martens Closed Cup Tester, 
using ASTM Standard D-93-79 or D-93-80, or a Setaflash Closed Cup Tester, using ASTM Standard D-3278-78.

- "it is not a liquid and is capable, under standard temperature and pressure, of causing fire through friction, absorption of moisture or spontaneous chemical changes and, when ignited, burns so vigorously and persistently that it creates a hazard."

- "it is an ignitable compressed gas as defined in 49 CFR $173.300 . . . "$

- "it is an oxidizer as defined in 49 CFR 173.151." (49 CFR 173.127 defines "oxidizer" as "a material that may, generally by yielding oxygen, cause or enhance the combustion of other materials").

EPA has assigned the EPA Hazardous Waste Number D001 to ignitable characteristic waste. The RCRA definition of ignitability is not to be confused with the various classifications of flammable materials under the International Classification System for hazardous materials that is used by the U.S. Department of Transportation (DOT). The DOT's Hazardous Materials, Substances and Waste Regulations are found at 49 CFR 171-178.

\section{What are corrosive wastes?}

Corrosive wastes are solid wastes that exhibit either of the following properties as defined at 40 CFR 261.22(a):

- "it is aqueous and has a $\mathrm{pH}$ less than or equal to 2 or greater than or equal to 12.5 as determined by a $\mathrm{pH}$ meter using either an EPA test method or an equivalent test method..."

- "it is a liquid and corrodes steel (SAE 1020) at a rate greater than $6.35 \mathrm{~mm}(0.250$ inch $)$ per year at a test temperature of $55^{\circ} \mathrm{C}\left(130^{\circ} \mathrm{F}\right) . "$ Corrosivity testing is conducted using the National Association of Corrosion Engineers (NACE) Standard TM-01-69 or an EPAapproved equivalent test method.

EPA has assigned the EPA Hazardous Waste Number D002 to corrosive characteristic waste. The DOT definition of "corrosive material" is found at 49 CFR 173.136.

\section{What are reactive wastes?}

Reactive wastes are solid wastes that exhibit any of the following properties as defined at 40 CFR 61.23(a):

- "it is normally unstable and readily undergoes violent change without detonating."

- "it reacts violently with water."

- "it forms potentially explosive mixtures with water."

- "when mixed with water, it generates toxic gases, vapors or fumes in a quantity sufficient to present a danger to human health or the environment."
- "it is a cyanide or sulfide bearing waste which, when exposed to $\mathrm{pH}$ conditions between 2 and 12.5, can generate toxic gases, vapors or fumes in a quantity sufficient to present a danger to human health or the environment."

- "it is capable of detonation or explosive reaction if it is subjected to a strong initiating source or if heated under confinement."

- "it is readily capable of detonation or explosive decomposition or reaction at standard temperature and pressure."

- "it is a forbidden explosive as defined in 49 CFR 173.51, or a Class A explosive as defined in 49 CFR 173.53 or a Class B explosive as defined in 49 CFR 173.88."

EPA has assigned the EPA Hazardous Waste iNumber D001 to reactive characteristic waste.

\section{What are incompatible wastes?}

Incompatible wastes are hazardous wastes which, if placed together, could result in potentially dangerous consequences. As defined at 40 CFR 260.10 , an "incompatible waste" is a hazardous waste which is unsuitable for:

- "placement in a particular device or facility because it may cause corrosion or decay of containment materials (e.g., container inner liners or tank walls); or

- "commingling with another waste or material under uncontrolled conditions because the commingling might produce heat or pressure, fire or explosion, violent reaction, toxic dusts, mists, fumes, or gases, or flammable fumes or gases."

\section{How is incompatibility determined?}

Once the physical and chemical properties of a hazardous waste have been adequately characterized, hazardous waste compatibility charts can be consulted to identify other types of wastes with which it is potentially incompatible. For example, Appendix V to both 40 CFR 264 and 265 presents examples of potentially incompatible wastes and the potential consequences of their mixture.

\section{Why must waste be characterized?}

Facilities handling wastes under RCRA must characterize their wastes: 1) to determine if the waste is hazardous and therefore regulated under RCRA Subtitle $C ; 2$ ) to determine if the waste is restricted by the Land Disposal Restrictions (LDR) and to ensure that the restricted waste meets the required treatment standards prior to land disposal; and 3) to verify that the waste received by offsite facilities is in fact the same waste described on the shipping manifest papers, and the waste has been characterized sufficiently to ensure safe management at a site. 


\section{DISCLAIMER}

This report was prepared as an account of work sponsored by an agency of the United States Government. Neither the United States Government nor any agency thereof, nor any of their employees, makes any warranty, express or implied, or assumes any legal liability or responsibility for the accuracy, completeness, or usefulness of any information, apparatus, product, or process disclosed, or represents that its use would not infringe privately owned rights. Reference herein to any specific commercial product, process, or service by trade name, trademark, manufacturer, or otherwise does not necessarily constitute or imply its endorsement, recommendation, or favoring by the United States Government or any agency thereof. The views and opinions of authors expressed herein do not necessarily state or reflect those of the United States Government or any agency thereof. 


\section{DISCLAIMER}

Portions of this document may be illegible in electronic image products. Images are produced from the best available original document. 
If the waste is determined to be hazardous, based on a representative sample, then the generator must manage the waste in accordance with the standards of 40 CFR 262. Owners and operators of hazardous waste treatment, storage and disposal facilities (TSDFs) are similarly required to obtain chemical and physical waste analysis data for all wastes received at their facilities by inspecting the generator waste characterization data and manifest/shipping papers, and recharacterizing the waste as necessary (40 CFR 264.13 and 265.13.) to verify generator data and support additional waste analysis requirements. •

\section{What are the waste sampling issues associated with these wastes?}

The two main waste sampling issues associated with the four categories of hazardous wastes defined above are: 1) ensuring the safety of personnel taking the samples; and 2) ensuring the representativeness of the samples.

Adequate personnel protective equipment (PPE) should be provided to assure the safety of personnel performing sampling activities. This should include protective clothing and any special tools/equipment (such as gloves, hoods, masks, air packs, etc. as applicable) required to prevent dermal contact, inhalation, ingestion, and other forms of exposure. All personnel performing sampling should be provided adequate training on ignitable, corrosive, reactive, and incompatible properties, the nature of the hazards associated with these wastes, and any special precautions necessary for the safe handling of the samples.

A representative sample must be obtained for all wastes that need to be characterized. Approved sampling procedures and test methods are provided in SW-846. Other EPA-approved methods also may be used (e.g., ASTM). Sampling procedures for liquids and solids are different as are the procedures used to sample wastes in various containers and other storage units (e.g., tanks, surface impoundments).

A suitable container (e.g., made of glass, amber glass, polyethylene, or special material) should be chosen to preserve the sample depending on which of the above characteristics are displayed by the source of the sample. If the sample reacts with the sampling bottle, it could pose a safety hazard to the personnel collecting the sample and those that handle it later, as well as affect the analytical results. SW-846 specifies appropriate sample containers, sample volumes, sample preservatives, holding times, quality assurance and quality control (QA/QC) procedures, and other related analytical considerations.

Handling of all samples should be done in accordance with proper QA, based on chain-of-custody procedures, and sufficient documentation should be generated to track the cradle-to-grave movement of the samples. Documentation should be available for activities associated with the collection, storage and analysis of the samples, as well as the final disposal of the sample after analysis.

\section{What are the storage requirements?}

Hazardous waste generators, subject to 40 CFR 262, and operators of interim status container storage units must comply with the storage requirements of 40 CFR 265 Subpart I; container storage requirements for permitted units are found in 40 CFR 264 Subpart J. These requirements include ensuring compatibility of the wastes with the container; storing ignitable and reactive wastes at least 15 meters ( 50 feet) from the facility's property line (this requirement does not apply to conditionally-exempt small quantity generators); not mixing incompatible wastes; not placing wastes in an unwashed and wet container that previously held an incompatible waste or material; and placing a physical barrier between incompatible wastes.

The hazardous waste tank storage requirements of 40 CFR 264/265 Subpart J require compatibility of the tank with the waste. The tank storage requirements also state that ignitable or reactive wastes cannot be placed in a tank unless 1) it is immediately treated to remove the characteristics and it does not result in dangerous reactions; or 2) it is stored or treated in such a way as to avoid any possible ignition or reaction. The tanks must also be at a safe distance from thoroughfares and adjoining property lines. The surface impoundment requirements of 40 CFR 264/265 Subpart $K$ and the waste pile requirements of 40 CFR 264/265 Subpart L state that ignitable or reactive wastes cannot be placed in such units unless the wastes and units satisfy the land disposal restrictions (40 CFR 268). It must also be immediately treated to remove the characteristics and avoid dangerous reactions or it must be protected from any possible ignition or reaction (certification is required for surface impoundments). Incompatible wastes must not be placed in the same surface impoundment or waste pile. They may also not be placed in piles or in an area where incompatible wastes or materials were previously placed unless the area has been decontaminated. Furthermore, wastes in piles must be separated from other incompatible wastes and materials by a physical barrier.

In addition to the above mentioned requirements, 40 CFR 264.17/265.17 requires that 1) measures be taken (e.g., no smoking) to separate and protect ignitable and reactive wastes from sources of ignition and reaction; 2) precautions be taken to avoid various dangerous reactions; and 3 ) documentation of compliance with these requirements.

\section{How do the Land Disposal Restrictions apply to these wastes?}

All hazardous wastes restricted for land disposal must be treated according to the LDR standards prior to their disposal. Unlike wastes that have been deemed hazardous under 40 CFR Subpart D (i.e., listed wastes), characteristic 
wastes, when treated to remove their characteristics, become non-hazardous solid wastes and no longer subject to regulation under RCRA Subtitle $C$.

Characteristic wastes (e.g., ignitable, reactive, or corrosive) are subject to the land disposal restrictions and their treatment and disposal must meet the requirements of 40 CFR 268. There are no specific requirements for incompatible wastes. Table 2 "Technology-Based Standards by RCRA Waste Code (40 CFR 268.42)" provides a list of the treatment technologies that must be used to treat ignitable, corrosive, and reactive wastes. In addition, Appendix VI to 40 CFR 268 provides examples of deactivation technologies that can be used to treat certain ignitable, corrosive, and reactive wastes. With the exception of D003 reactive cyanide wastewater or nonwastewater, dilution is an acceptable treatment method if it is part of a wastewater treatment system permitted under the Clean Water Act.

\section{What restrictions or considerations apply to the handling and transport of these wastes?}

The DOT's Hazardous Materials, Substances and Waste Regulations (49 CFR Parts 171-178) outline how these wastes, and other hazardous wastes/materials, should be packaged and transported. Requirements for labeling, packaging, and shipping of hazardous materials are presented in the Hazardous Materials Table found at 49 CFR 172.101 and discussed in Reference \#(3).

Special precautions necessary for handling corrosive wastes include ensuring that the material of construction of the container or other storage device has been selected to withstand the harsh properties of these types of wastes. Sometimes corrosive wastes/materials that have either very high pH (highly caustic) or very low pH (highly acidic) can corrode their containers, resulting in an accidental release with potentially adverse consequences. In addition, accidental neutralization could result in the generation of heat, overpressure and other undesirable side effects. Special precautions for reactive wastes would include providing for overpressure protection through the use of pressure relief valves, thermal relief, etc. Special precautions for ignitable wastes include no smoking or open flames, the use of nonsparking tools, and explosive proof electrical lighting and wiring.

Some of the issues associated with the safe transportation of the four hazardous wastes streams include heat generation (from exothermic reactions), generation of flammable gas(es), generation of toxic gas(es), pressure buildup in containers during transit, polymerization reactions, and fire propagation. In addition, there might be some unknown synergistic reactions which could adversely affect the transportation of mixed waste streams. Containers used for transporting hazardous waste streams should have safety relief devices to protect against the scenarios identified above. Generally, containers with special fittings are used to transport these waste streams. These fittings could include thermal reliefs, pressure reliefs, special materials of construction for connections to withstand harsh environments (corrosive, reactive, ignitable wastes), flame arresters (for ignitable wastes), etc.. They are normally designed to prevent unsafe conditions during the loading, transporting and unloading of hazardous wastes.

\section{What are the safety issues associated with these wastes?}

The safety issues include adequate identification of hazards associated with the handling, storage and transport of the four waste streams, and providing adequate training to ensure the safety of personnel dealing with the waste streams. Training provided should be documented and the training records should be available for inspection. Safe operating procedures should be available for routine activities associated with the handling of the waste streams. These procedures should emphasize the hazardous properties of the wastes, such as corrosivity, reactivity, ignitability, and toxicity affecting the health and safety of the personnel that deal with these wastes.

Incompatibility of commingled waste streams is a major concern because it is very difficult to characterize. It is recommended that a compatibility chart be prepared for every waste stream generated in the facility and all its properties studied carefully before any wastes are commingled.

Personnel involved in the day-to-day handling of the wastes should also be familiar with the facility's safe emergency response procedures and facility plot plans. Periodic drills should be conducted to ensure that the emergency plans are effective.

Adequate preventive maintenance of equipment used for handling waste streams should be provided. Adequate detection and monitoring systems should be in place to assure that waste container leaks are detected in a timely manner for early activation of mitigation systems.

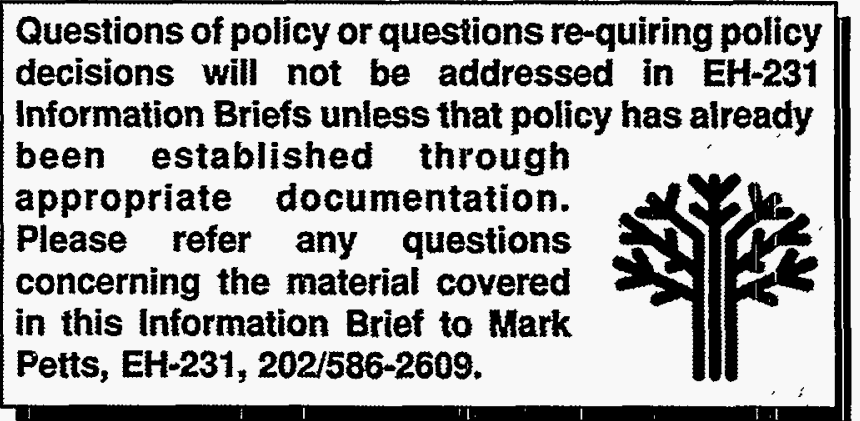

